\title{
Evaluation the Observance of Patients Right Charter by Nurses in Elderly
}

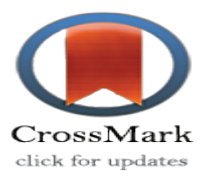

\section{inpatient Centers of Khuzestan}

\section{*Jafari $\mathrm{Z}^{1}$, Abdyazdan $\mathrm{Gh}^{1}$}

1- Master of Nursing, Islamic Azad University, Khorasgan Branch, Isfahan, Iran (Corresponding Author)

E.mail: zeynabjafary1369@gmail.com

\section{Abstract}

Introduction: Every patient has legal rights without any discrimination when $\mathrm{s} / \mathrm{he}$ refers to health centers and it must be observed by all of the providers' services.

Method: The current study is a descriptive-sectional study. The samples of study were containing of 175 of patients with the ages of more than 65 years old that were chosen by easy sampling method. The gathering tool of data was the researcher's built questionnaire. After the completion of questionnaires, the data were analyzed by means of SPSS software Ver.22.

Results: As the results of study, the elderlies that were attended in this study reported as follow: the amount of their observance's rights in secrecy level and protection the privacy $(84.6 \%)$, in the level of privilege of cares and appropriate remedy $(77.1 \%)$, presenting the needful information to patients $(54.3 \%)$, protection the patient's independence $(54.9 \%)$, the right of having calmness (61.7\%) and absence of non-appropriate behaviors of nurses team $(68 \%)$ that were in high level. And just in the domain of investigation of protests, the amount of observance rights in most patients (37.1\%) that was calculated in an average level.

Conclusion: This study showed that nurses in most areas they respect the rights of the elderly.

Keywords: Patients' rights, Elderlies, Nurses.

Received: 1June 2019

Accepted: 13 August 2019

\begin{tabular}{|l|l|}
\hline \multicolumn{3}{|c|}{ Access this article online } \\
\hline
\end{tabular}




\title{
بررسى رعايت مفاد منشور حقوق بيماران توسط بِ ستار ان در مر اكز بسترى سالمندان استان
}

\author{
خوزستان

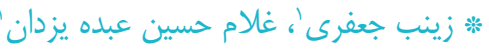

ا - كارشناسى ارشد يرستارى، دانشكاه آزاد اسلامى، واحد خوراسكان، اصفهان، ايران (نويسنده مسئول)

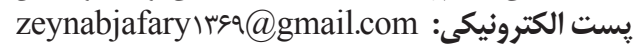

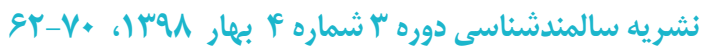

\begin{abstract}
مقدمه: هر بيمار در زمان مراجعه به مراكز درمانى بدون هيج تبعيضى داراى حقوق قانونى است كه رعايت آن از سوى ارائه دهندكان خدمت الزامى است.

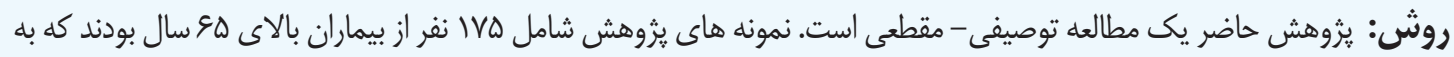

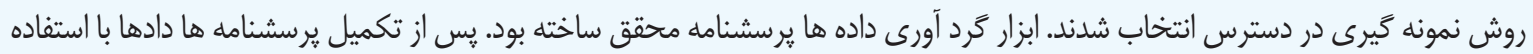

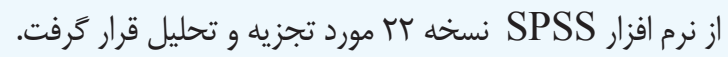

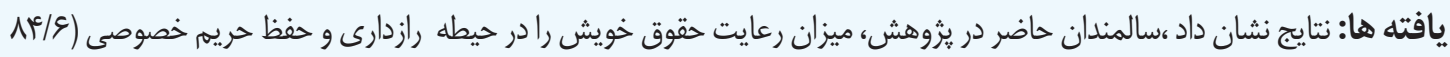

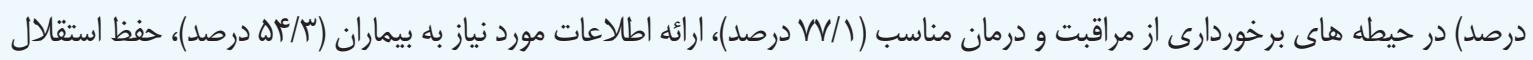

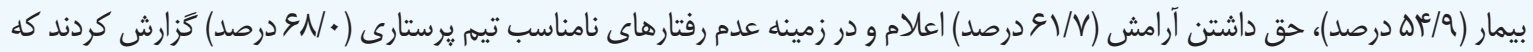

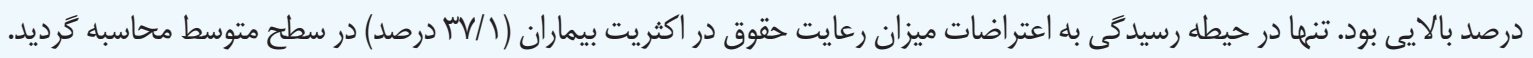

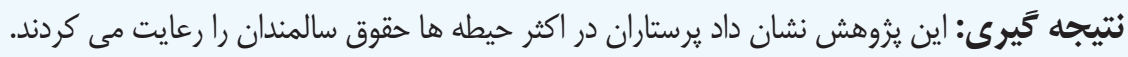
كليدوازه ها: حقوق بيماران، سالمندان، برستاران. تاريخ دريافت:
\end{abstract}

بسيارى از كشورها، به منظور دستيابى به رضايت بيماران ،مقررات

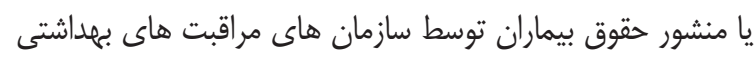

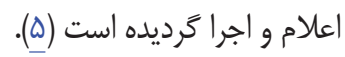
در سالماى قبل يرسنل درمانى بايد براى بيمار تصميم ميكرفت در حاليكه در تعاريف جديد، تغيير اساسى در برداشت عمومى از نقش بيمار، مراقبتهاى بهداشتى و حيطه اختيارات و تصميم كيرى بيماران ايجاد شده است (؟). يرستاران به عنوان اعضايى از نظام سلامت كه بيشترين تماس را با بيماران و خانواده هايشان دارند، بايد نسبت به قوانين و

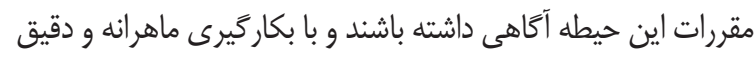
آن، موجب دستيابى به استقال حرفه اي، حفظ حقوق خود و بيماران إنان و كاهش مواجهه با مشكلات قانونى شوند (V). يكى از فصول مهم اصلاحات در نظام سلامت، آكاهى

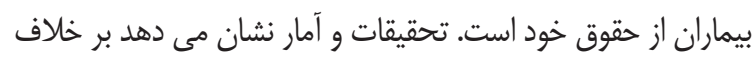

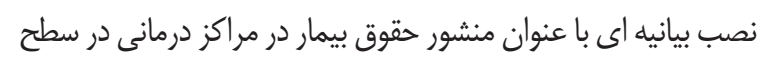

\section{Lovด} حفظ شأن و منزلت انسان و رعايت اخلاق و حقوق فردى و اجتماعى انسان ها از موضوعاتى است كه در سال هاى اخير توجه جوامع مختلف را به خود جلب كرده است. در همين زمينه مفهوم

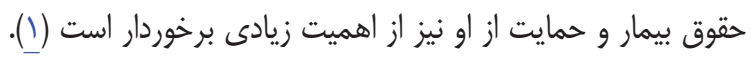

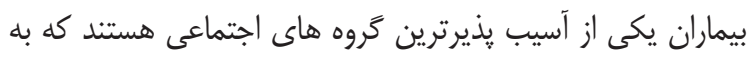
دليل تحمل درد و رنج ناشى از بيمارى توانيييهاى معمولى خود را از از

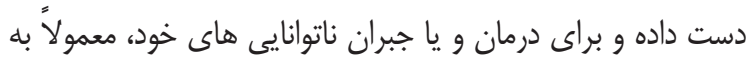
سيستم هاى ارائه دهنده ى خدمات بهداشتى و سلامتى اعتماد كامل

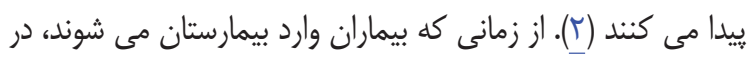
معرض نقض حقوق شان قرار مى گيرند زيرا كه اولويت در مورد يك فرد بيمار، كسب موقعيت سلامتى او هست و نه بيان حقوق او (ِّا).

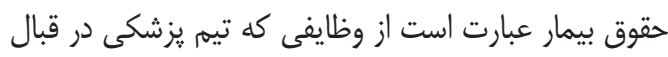

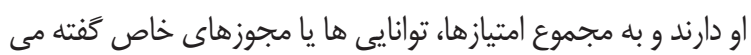

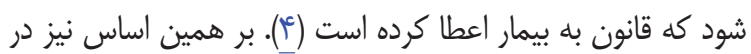


اين مطالعه توصيفى - تحليلى مقطعى يس از كسب مجوزهاى

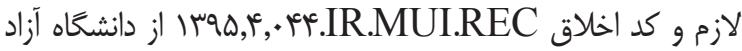
اسلامى واحد خوراسكان بر روى يرستاران مراكز بسترى سالمندان

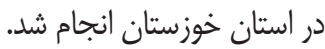

ابزار گَرد آورى داده ها، يرسشنامه محقق ساخته عب سوالى بود. يرسشنامه در دو بخش كلى آماده كرديد، بخش اول شامل

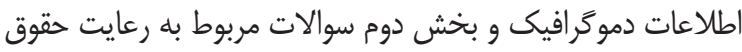

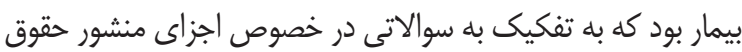

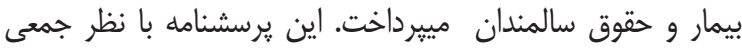
از اساتيد دانشكاه آزاد اسلامى واحد اصفهان (خوراسكان) از جهت

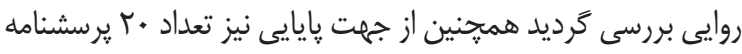

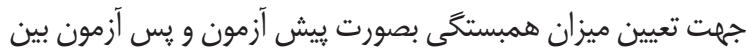

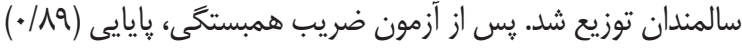
به دست آمد. جهت تجزيه وتحليل اطلاعات ميانكَين امتيازات هر

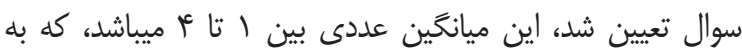

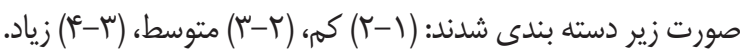
در اين يزوهش محقق از جمعيت در دسترس با روش نمونه

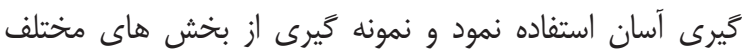

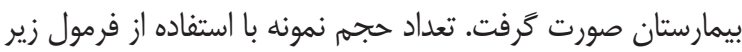

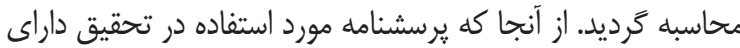
طيف ليكرت با مقادير · تأ أ بود براى تعيين حجم نمونه ابتدا مقدار

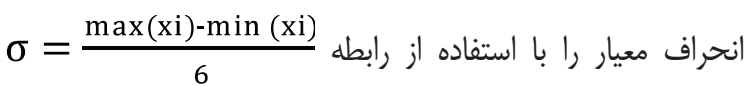
تخمين زده و سبس با استفاده از فرمول

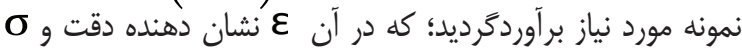
سطح خطا را نشان مى دهد. اكر سطح خطا ه درصد و دقت / /.

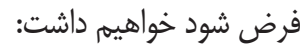

$n=\left(\frac{1.96 \times 0.67}{0.1}\right)^{2}=172.44 \cong 173 \quad \sigma=\frac{4-0}{6}=0.67$ براى بررسى آمارى داده هاى حاصل از يزوهش، متغيرهايى

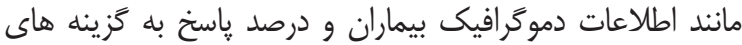
يرسشنامه، از طريق آمار استنباطى مورد تجزيه و تحليل قرار كرَفتند.

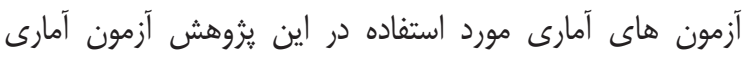

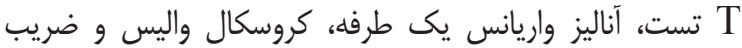

$$
\text { همبستخى ييرسون بود. }
$$

معيارهاى ورود واحدهاى مورد يزوهش به مطالعه:
آكاهى عمومى، نسبت به سال هاى كَذشته تفاوت قابل توجهى در

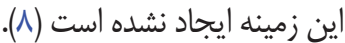

حقوق تعيين شده براى بيماران در منشورهاى دنيا كم و بيش مشابه است و شامل حق برخوردارى از اطلاعات، حق محرمانه بودن

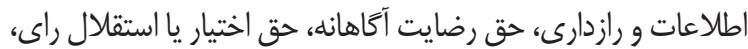
حق برخوردارى از آموزش سلامت، حق ابراز اعتراض و شكايت و حق جبران خسارت مى باشد (9). با توجه به مطالب كفته شده اين نكته

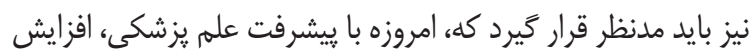
هزينه ها و افزايش جمعيت سالمندى، توجه به مسائل اخلاقى و موضوعات حقوقى در يرستارى و به ويزه در مراقبت ازسالمندان بيش از يبي اهميت يافته است (•). در ايران آمار سالمندى براساس سرشمارى سال هوسا، و/TV درصد بوده است (1). از سويى سالمندى بخش مهمى از زندكى است و امروزه جوامع با افزيش بيش از ييش سالمندان مواجه اند و نيز با توجه به مشكلات ويزه اى كه فقط دراين دوره بروز مى كنند، توجه

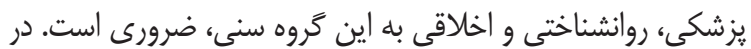
همين راستا، كوششهاى بسيارى براى بهبود سطح كمى و كيفى رئى زندگى سالمندان در جامعه صورت مى گيرد، و از مهمترين مواردى كه در بهبود زندگى سالمندان مطرح است، رعايت برخى ملاحظظات اخلاقى و حقوقى در رابطه با آنهاست (I) (I).

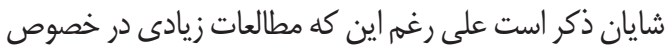
بررسى ميزان رعايت منشور حقوق بيماران در داخل و خارج كشور

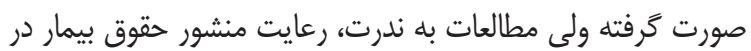
رابطه با سالمندان ارزيابى نموده اند. بيشتر مطالعات، آكاهى يرستاران حران را از حقوق بيماران و نه صرفا بيماران سالمند سنجيده اند. بر همين اساس آكاهى ناكافى يرستاران از مسائل اخلاقى و حقوقى بيماران سالمند، باعث آسيب هاى جسمى و روحى، تحميل هزينه، كاهش آثرافي

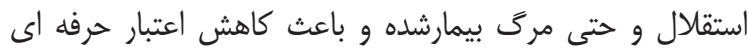
يرستاران مى شود (1) (1). يرستاران با آكاهى از اين مسائل مى توانند، سطح مراقبت هاى يرستارى را به ويزه در سالمندان ارتقا بخشند. با توجه به إنها أمارهاى متفاوت از دانش يرستاران در زمينه مسائل اخلاقى و حقوقى لهان مراقبت از بيمار و فقدان مطالعه در حوزه مراقبت از سالمندان، محقق

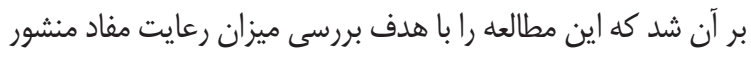
حقوق بيماران توسط يرستاران در مراكز بسترى سالمندان استان خوزستان در سال ع وسا انجام دهد.

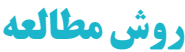


نمونه ها به تعدادى از يرسنل يرستارى آموزش داد تا يرسشنامه ها را توزيع نموده وبه بيماران جهت ير كردن يرسشنامه توضيحات لازم را ارائه نمايند محقق نيز به صورت دوره اي روى كار آنها نظارت داشت. در اين يزوهش به منظور تجزيه و تحليل داده ها، پِ از جمع آورى يرسشنامه ها، داده ها وارد نرم افزار SPSS نسخه بr شدند.

\section{كافته ها}

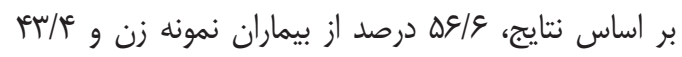

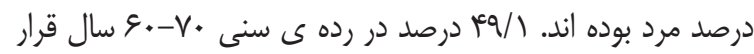

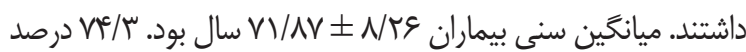

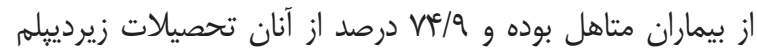
داشته اند. تعداد فرزند در //أ درصد از بيماران نمونه و-أ فرزند

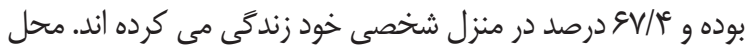

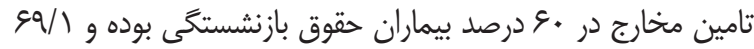

درصد از آنان از نظر اقتصادى مستقل بوده اند (جدول ()
() () تمايل به شركت در مطالعه

$$
\text { r) داشتن شرايط سنى Q }
$$

r) توانايى تكميل يرسشنامه يا انجام مصاحبه ،فقدان معلوليت

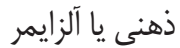

א) واحدهاى مورد يزوهش حداقل به مدت سه روز يا بيشتر

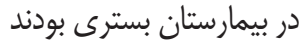

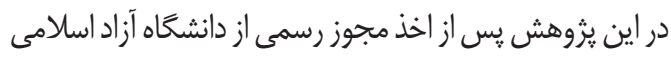
اصفهان (واحد خوراسگان) از بيمارستانهاى سطح استان خوزستان تا ير شدن حجم نمونه استفاده كَرديد. بدين منظور، پِس از ارائه مجوز

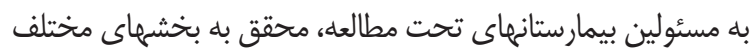

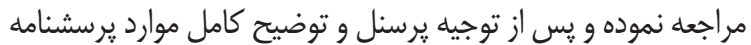
به آنان، درخواست شد كه برسشنامه ها در شيفت هاى مختلف در اختيار سالمندان با شرايط فوق قرار داده شود و در صورتى كه از سواد كافى برخوردار نبودند برسشنامه به صورت شفاهى برايشان خوانده

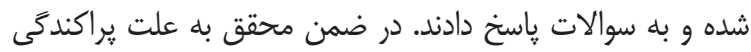

\begin{tabular}{|c|c|c|c|c|c|}
\hline انحراف معيار & ميانگَين & درصد & تعداد & دسته & متغير \\
\hline 1.rE & VI.AV & 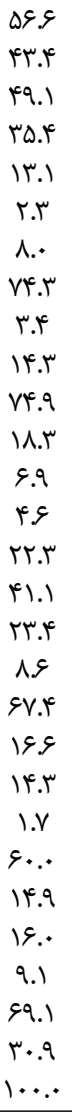 & 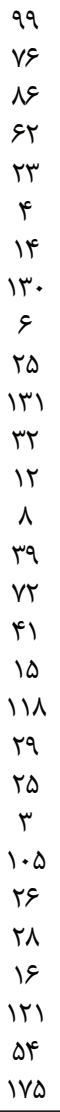 & 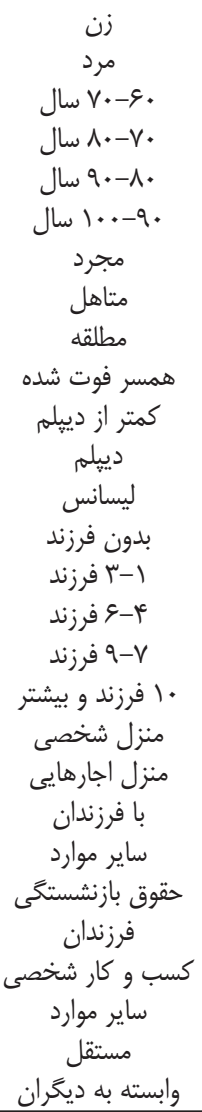 & 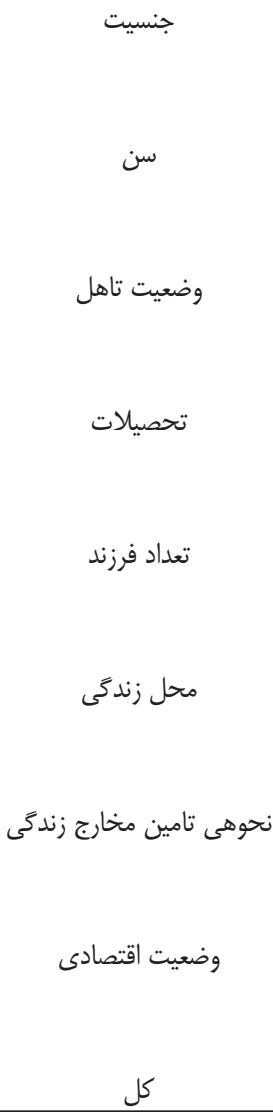 \\
\hline
\end{tabular}


و عدم رفتارهاى نامناسب تيم برستارى (·N دمرصد) در سطح بالايى بوده است. و تنها در حيطه ى رسيدگى به اعتراضات ميزان رعايت حقوق در اكثريت بيماران (IV/I درصد) در سطح متوسط

مشاهده شد (جدول عاب).
بر اساس نتايج، و مطابق با نظر اكثريت بيماران حاضر در

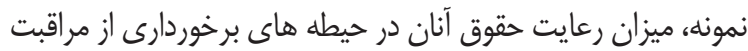
و درمان مناسب (W/I درصد)، ارائه اطلاعات مورد نياز به بيماران

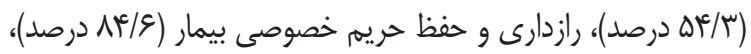

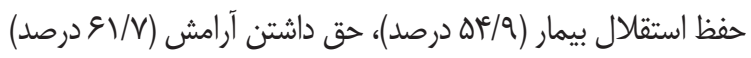

جدول ז: توزيع فراوانى واحدهاى مورد بُروهش بر اساس ميزان رعايت حقوق بيماران

\begin{tabular}{|c|c|c|c|c|c|c|c|c|}
\hline \multicolumn{2}{|c|}{ كل } & \multicolumn{2}{|c|}{ زياد } & \multicolumn{2}{|c|}{ متوسط } & \multicolumn{2}{|c|}{ كم } & \multirow{2}{*}{ ميزان رعايت حقوق } \\
\hline درصد & تعداد & درصد & تعداد & درصد & تعداد & درصد & تعداد & \\
\hline & & & & & & & & \multirow{9}{*}{ 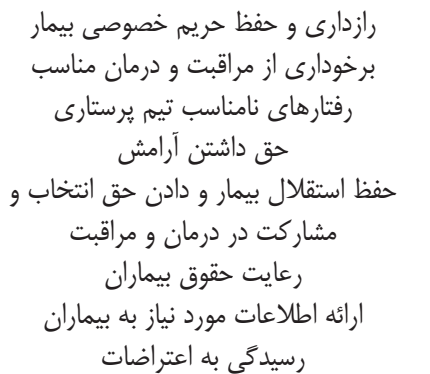 } \\
\hline $1 \cdots \cdot$ & $I V D$ & 1F. & $1 F \lambda$ & $1 T .9$ & r & r.q & $\Delta$ & \\
\hline $1 \cdots \cdot$ & IVD & W.I & מזו & 19.5 & me & r.f & $\varepsilon$ & \\
\hline $1 \cdots \cdot$ & IVD & sᄉ.. & 119 & 9.1 & 19 & r..q & f. & \\
\hline $1 \cdots \cdot$ & IVD & SI.V & $1+1$ & ra.f & gr & $r .9$ & $\Delta$ & \\
\hline $1 \cdots \cdot$ & $I V \Delta$ & Df.q & $q$ & ५^.q & $9 \wedge$ & 9.1 & 11 & \\
\hline $1 \cdots \cdot$ & $I V D$ & $\Delta V . V$ & 1.1 & fi.l & $v r$ & 1.1 & $r$ & \\
\hline $1 \cdots \cdot$ & IVD & س. & $9 \Delta$ & $f+$. & V. & Q.V & 1. & \\
\hline $1 \cdots \cdot$ & $I V D$ & TV.I & $\varepsilon_{\Delta}$ & DF.q & $9 \varepsilon$ & ᄉ.. & If & \\
\hline
\end{tabular}

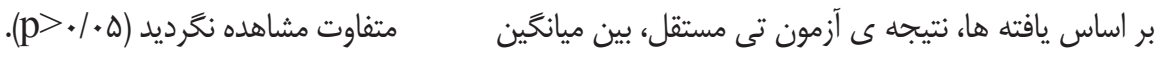

ولى طبق نتيجه ى آزمون آناليز واريانس يكطرفه تفاوت

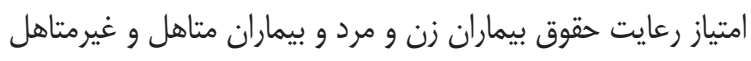
معندارى بين ميانكَين امتياز رعايت حقوق بيماران در رده-هاى التيز (مجرد، مطلقه يا از همسرفوت شده) تفاوت معنادارى نشان نداد

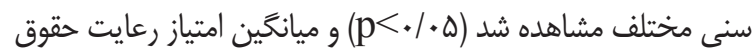
$(p>\cdot / \cdot \Delta)$

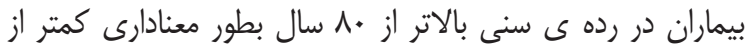
بيمار ان با سن كمتر بوده است.(جدول بّ) و بر اساس نتيجه ى آزمون كراسكال واليس نيز اختلاف معنادارى بين امتياز رعايت حقوق بيماران و با سطوح تحصيلات آنرات جدول "ا: مقايسه ميانكَين امتياز رعايت حقوق بيماران بر اساس متغيرهاى زمينه ايى

\begin{tabular}{|c|c|c|c|c|c|c|}
\hline p-مقدار & آماره & انحر اف معيار & بيانكَين & تعداد & دسته & متغير \\
\hline \multirow[t]{3}{*}{.191} & $\mathrm{t}=1 . .^{\mathrm{f}} \cdot 9$ & Fr & $\mu .$. & 99 & زن & جنسيت \\
\hline & & גז. & ז. ^. & ve & مرد & \\
\hline & & זr. & r. 10 & $\wedge \varepsilon$ & ع.- V. & \\
\hline \multirow[t]{3}{*}{.015} & $F=r . r V r$ & (f) & r.qu & gr & . & 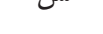 \\
\hline & & سז. & r.qq & TV & بالاتر از • & \\
\hline & & tef & r.qv & in & سال & وضعيت \\
\hline \multirow[t]{3}{*}{ rif } & $\mathrm{t}=1 . \mathrm{YFA}$ & q9 & $r . . \varphi$ & riv. & غيرمتاهل & \\
\hline & & q9 & $r . \Delta$ & וाו & ك. & تاهل \\
\hline & & $.2 \mathrm{~V}$ & r.9v & rT & كمتر از دييله & \\
\hline.$f \cdot V$ & $\chi^{r}=1 . \vee 99$ & f) & r.qV & $\pi$ & ليسانس & تحصبلات \\
\hline
\end{tabular}

رابطه معكوس و معنادارى بين ميزان رعايت حقوق بيماران و تعداد بر اساس يافته ها، و طبق نتيجه آزمون تى مستقل، بين

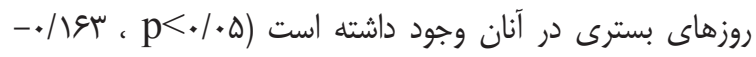

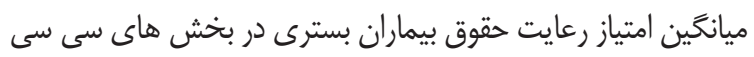

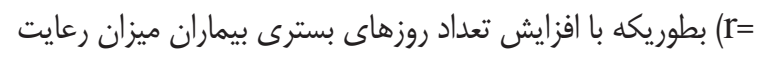

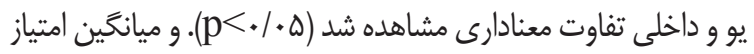
حقوق آنان كاهش داشته است و بالعكس. با محاسبه ضريب همبستخى ييرسون، رابطه معنادارى بين

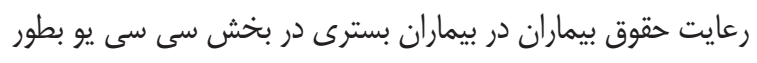
ميزان رعايت حقوق بيماران و تعداد دفعات بسترى در آنان مشاهده معنادارى بيشتر بود. با محاسبه ضريب همبستى بيرسون مشخص كَرديد كه 
مشاهده شد (ه•/p) و ميانكَين امتياز رعايت حقوق بيماران با

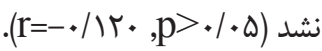
بيمه روستايى و بيماران بدون بيمه بطور معنادارى بيشتر از ساير ولى طبق نتيجه ى آزمون كراسكال واليس تفاوت معنادارى بيماران مشاهده شد (جدول بأ). بين ميانكين امتياز رعايت حقوق بيماران با بيمه هاى متفاوت

جدول fأ: مقايسه ميانگين امتياز رعايت حقوق بيماران بر اساس شرايط بسترى

\begin{tabular}{|c|c|c|c|c|c|c|}
\hline سطح معنادارى & آماره & انحراف معيار & ميانگين & تعداد & دسته & متغير \\
\hline \multirow[t]{4}{*}{$. .1 .<$} & \multirow[t]{4}{*}{$t=\{. r)}$. & 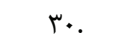 & r.lf & 91 & سى سى يو & بخش بسترى \\
\hline & & ev. & r.M & 99 & داخلى & \\
\hline & & r. & $r . \cdot V$ & $|Q|$ & . & \\
\hline & & عَ & r.vq & re & " & \\
\hline \multirow[t]{4}{*}{ וז. ון. } & \multirow[t]{4}{*}{ "r } & 4. & $r . \cdot V$ & $\Delta F$ & يك بار & مدت بسترى \\
\hline & & rV. & r... & is & دوبار & \\
\hline & & שr. & r.Ir & ऍa & جهار بار و & \\
\hline & & f. & r.qY & r. & بيشتر & \\
\hline \multirow[t]{4}{*}{$11 \pi}$. & \multirow[t]{4}{*}{$\mid r \cdot .-=r$} & ra. & $r . r^{c}$ & 91 & اجتماعي & دفعات بسترى \\
\hline & & pie. & r.q. & is & خدمات & \\
\hline & & er. & r.ıQ & Tf & درمانى & \\
\hline & & f. & r.人 & $\Delta$ & روستيى & \\
\hline .11. & $\chi^{r}=11.1 \Delta \xi$ & щ. & سא. & $q$ & بدون بيمه & نوع بيمه \\
\hline
\end{tabular}

همم جنس و غير از يرسنل بود كه بيش از • ٪\% بيماران كزارش كردند. در ادامه، درحيطه هاى برخوردارى از مراقبت و درمان مناسب، بران

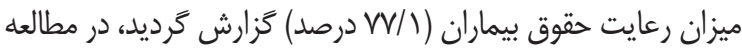
اى كه نصيريانى و همكاران در سال (عNبا) انجام دادند ميزان

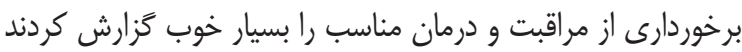
كه با نتايج يزهش حاضر همخوانى دارد (ع). درحيطه عدم رفتارهاى

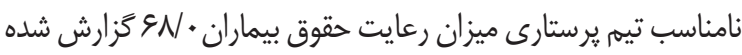

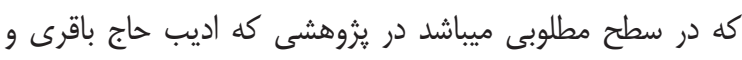
ذهتاب جى در سال (سوسا) انجام دادند ميزان رعايت حقوق بيماران در حيطه عدم رفتارهاى نامناسب تيم برستارى بسيار خوب كزارش

شده است كه با نتايج اين يُزوهش همخوانى دارد (V).

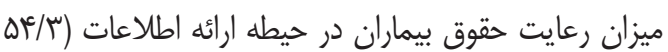
درصد) در سطح مطلوبى بوده است. يزوهش امينى و همكاران

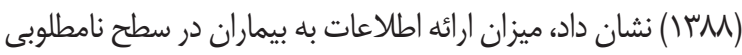

ميباشد كه با نتايج اين يزوهش همخوانى ندارد (IV). در رابطه با ميزان رعايت حقوق بيماران در زمينه حق انتخاب

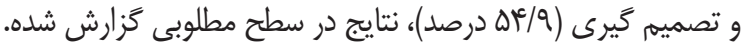
در مطالعه اى كه قلجه و همكاران (بوسا) انجام دادند نتايج نشان

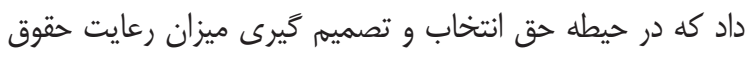
بيماران در سطح متوسطى قرار داشت (1).). همجنين نتايج مطالعه توسط رحمانى و همكاران (عرسا) نشان داد كه اكثريت بيماران
بر اساس (جدول r)، نتايج يزوهش نشان داد كه از نظر اكثر

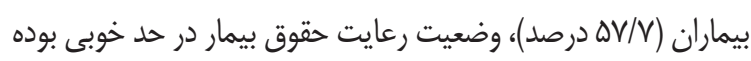
است. ميزان رعايت منشور حقوق بيمار در مطالعات مختلف متفاوت بوده است. رنغرز جدى و ربيعى (هرسا) در مطالعه خود نشان دادند

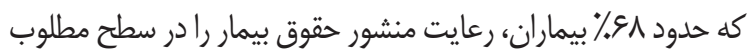
ميدانستند (4). نتايج يثوهش اركوازى و همكاران در سال (Tوسار) نشان داد در مجموع V درصد حقوق بيمار رعايت مى شود (1). به نظر ميرسد ميزان رعايت منشور حقوق بيمار بسته به فرهنگ

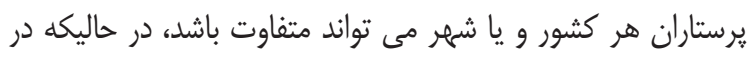
رشته يرستارى تأكيد زيادى روى اين جنبه شده است ولى اجرا در مناطق مختلف متفاوت ميباشد. بر اساس يافته هاى يزوهش حاضر، ميزان رعايت حقوق

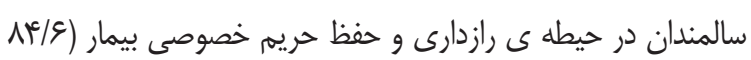
درصد)، ميباشد كه بيشترين ميزان رعايت را داشته است،در مطالعه اى كه اديب حاج باقرى و ذهتاب جیى در سال (سوجا() انجام دادند،

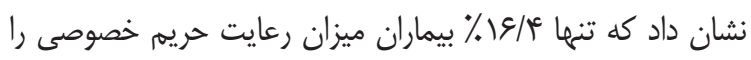

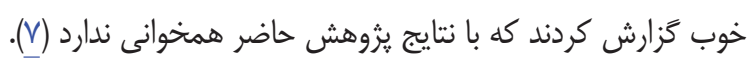
در رابطه با ميزان رعايت حريم خصوصى، بيشترين فراوانى موارد رعايت نشده مربوط به ديده شدن قسمت هايى از بدن توسط افراد 
بيمار نيز از طرف كاركنان كروه درمان ارتقا يافته است كه با نتايج اين يثزوهش همخوانى ندارد (؟ه). بر اساس نتايج (جدولئ)، بين ميانكَين امتياز رعايت حقوق

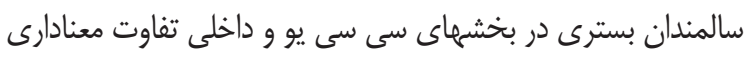

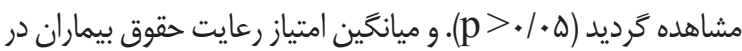
بيماران بسترى در بخش سى سى يو بطور معنادارى بيشتر بود.شايد

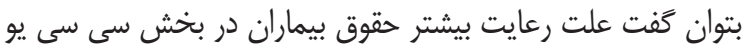

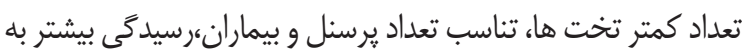
بيمار ان،داشتن فضاى كافى براى هر بيمار، وجود امكانات و تجهييزات بيشتر باشد. در يخوهش اركوازى و همكاران در سال (זوسا) نيز

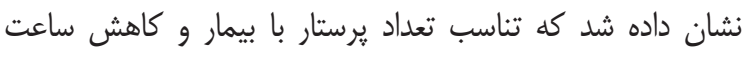

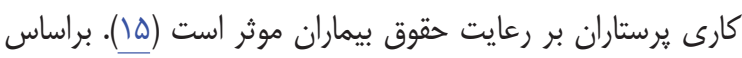
نتايج (جدولئ)، رابطه معكوس و معنادارى بين ميزان رعايت حقوق بيماران و تعداد روزهاى بسترى در آنان وجود داشته (ه+/.p>

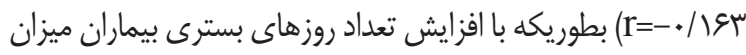
رعايت حقوق آنان كاهش يافته است و بالعكس. يُوهش بصيرى مقدم و همكاران (•وسا) نشان داد ميزان رعايت حقوق بيماران با بانه

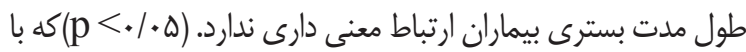
نتايج اين يخوهش همخوانى نداشت (هآ). در ادامه (جدولَ)، مشاهده ترديد كه رابطه معنادارى بين ميزان رعايت حقوق بيماران و تعداد دفعات بسترى آنان مشاهده نشد الشدان نتايج يزوهش بصيرى مقدم و همكاران

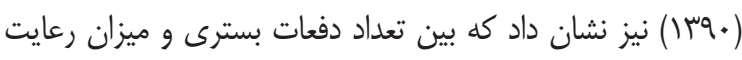

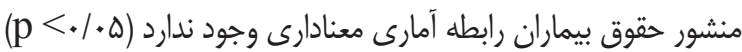

بر اساس (جدولئ)، تفاوت معنادارى بين ميانخين امتياز

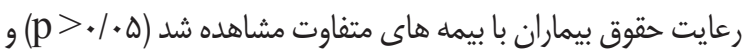
ميانخين امتياز رعايت حقوق بيمار ان با بيمه روستايى و بيماران بدون بيمه بطور معنادارى بيشتر از ساير بيماران مشاهده شد. در تبيين علت احتمالى مغايرت در يافته ها ميتوان به اين نكته اشاره نمود كه مطالعات مذكور در بخشهاى مختلف و در جمعيتى متفاوت از مطالعه حاضر انجام شده اند، لذا تفاوت در اين موارد منجر به تفاوت در نتايج شده است. در مورد عوامل مؤثر بر ميزان رعايت حقوق بيماران سالمند توسط يرستاران، سه علت مهمه به ترتيب شامل

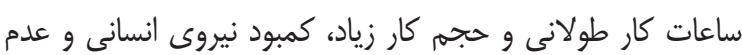
آكَاهى برستاران از قوانين بود.

\section{نتيجه كيرى نهايى}

معتقد بودند كه برستاران استقلال آنان را در بعد ميزان اطلاعات داده شده به آنان و ميزان مشاركت دادن آنان در فرآيند تصميم كيرى هاى درمانى در حد ضعيف رعايت نمودند كه با نتايج اين بزوهش همخوانى ندارد (19). در اين يزوهش مشخص گر ديل، ضعيفترين عملكرد در رعايت حقوق بيماران مربوط به حيطه ى رسيدگى به اعتراضات با (IV/IT)

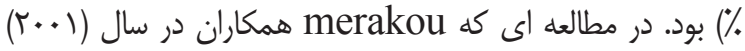
انجام دادند رعايت حق اعتراض بيماران در سطح ضعيف كزارش

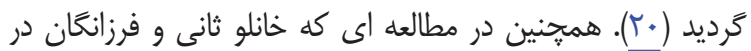
سال (أوجسا) انجام دادند نشان داد ميزان رعايت حق رسيدگى به ديه اعتراضات و شكايات در حد ضعيفى ميباشد كه با نتايج اين يثوهش همخوانى داشت. انجام هر كارى به روش صحيح و درست مستلزم آكاهى از آن است،براى رعايت حقوق بيماران نيز شرط اول داشتن آكاهى كافى از اين حقوق است؛ وقتى يرستاران از اين حقوق آَّاه

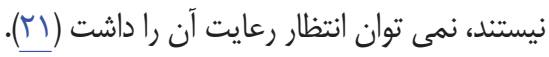
بر اساس يافته هاى (جدول سّ)، تفاوت معنادارى بين ميانگين

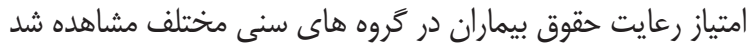
(p> و ميانخين امتياز رعايت حقوق بيماران در گروه هاى سنى بالاتر از •م سال بطور معنادارى كمتر از بيماران با سن كمتر بودها

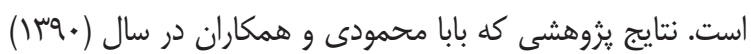
انجام دادند نشان داد در كروههاى مختلف سنى از نظر ميزان رعايت مايت حقوق بيماران اختلاف معنى دارى مشاهده نشد كه با نتايج يزوهش دانش

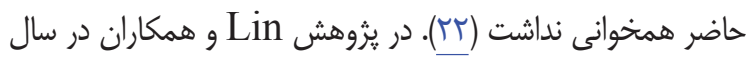
11 +r، نتايج نشان داد كه رعايت حريم بيمار با سن رابطه معكوس دارد كه با نتايج اين يزوهش همخوانى دارد (سآ). همجنين بر اساس نتايج اين جدول، اختلاف معنادارى بين امتياز رعايت حقوق بيماران

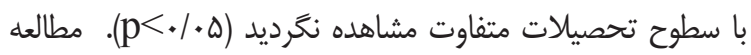
دادخواه و همكاران (سوسו) در اردبيل نشان داد، بين تحصيلات

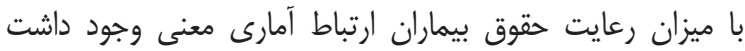

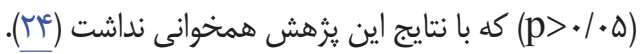
در ادامه در (جدولّ)، مشاهده گرديد، بين ميانخين امتياز رعايت حقوق بيماران زن و مرد با سطوح تحصيلات متفاوت تفاوت معنادارى وجود نداشت (ه+/p). فرزانغان در سال (أوسا) انجام دادند نتايج مشابه با اين تحقيق داهيق بدست آمد (آ). از سويى ديخً، يزوهش بصيرى مقدم و همكاران (•qسا) نشان داد بين ميزان رعايت منشور حقوق بيمار در سطوح مختلف تحصيلى بيماران تفاوت آمارى معنى دارى وجود دارد. به

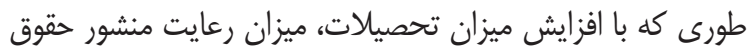


و محدود بودن ملاقات كنندكان و داشتن موقعيت ويثه از جهت نوع بيمارى باعث شده يرستاران رعايت بيشترى در جهت مناسب سازى

$$
\text { موقعيت و شرايط بيماران انجام دهند. }
$$

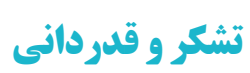

نويسندگًان كمال تقدير و تشكر را از كليه شركت كنندگان

دراين مطالعه اعلام ميدارند. اين مطالعه حاصل از پايان نامه با كد

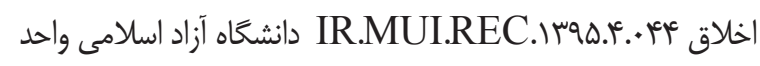

$$
\text { خوراسگان مى باشد. }
$$

\section{References}

1. valimaki M, Kuosmanen L,Kark kainen J,KjervikDK. Patients' rights to complain in Finnish psychiatric care: an overview. Int J Law Psychiatry 2009; $32(3): 184-8$.

2. Eteraf Oskouei M, Tabrizi J S, Gharibi F, Asghari Jafarabadi M. Patient's Rights Protection through an Education-Based Intervention. Iran J Med Law. 2013; 7 (25) :13 - 27 [Persian].

3. Babamahmoodi, F. Meftahi, M. Khademloo, M. Hesamzadeh, A. (2011). Observation of patient's right charter in Mazandaran teaching hospitals: patients view. Iranian Journal of Medical Ethics and History of Medicine. 4: 37 - 44.

4. Ozdemir MH, Ergonea AT, Sonmez A, Can IO, Salacin S. (2014), The Approach taken by the physicians working at educationalhospitals in Izmir towards patient rights, Pateint Education, 61(1), $87-92$.

5. Mastaneh Z1, Mouseli L, Patients Awareness of Their Rights: Insight from a Developing Country,International Journal of Health Policy and Management 2013; 1(x), 1-4.

6. Sarbaz M, Kimiafar Kh. Comparison of Patient's Rights in Developed Countries and Suggestion a Proper Model for Iran. Health Information Management. 2011: 2 (18);1 - 10 [Persian].

7. Adib hajbagheri $m$, Zehtab s. Surveying the privacy of elderly patients and their satisfaction with privacy in selected hospitals in Isfahan province. Medical Ethics Quarterly.2014; 8 (29): 97-120 [Persian].

8. Vaskooei Eshkevari K, Karimi M, Asnaashari H, Kohan N.[ The assessment of observing patients' right in Tehran University of Medical Sciences' hospitals].Iranian Journal of Ethics and History

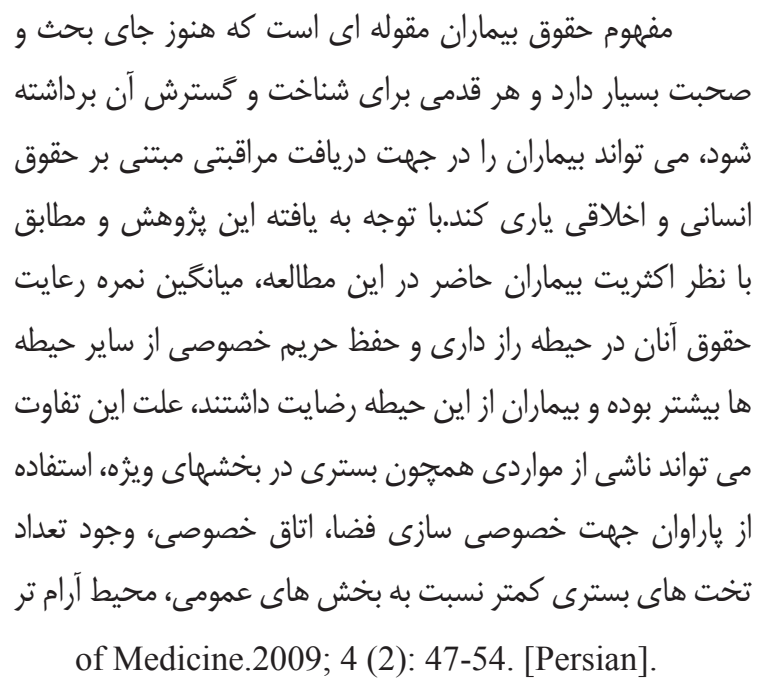

9. Hadian Jazi Z, Dehghan Nayeri N. Barriers in the Performance of Patient's Rights in Iran and Appropriate Offered Solutions Review Article. J Holist Nurs Midwifery. 2014; 24 (4): 69 - 79 [Persian].

10. Adib hajbagheri M, Safa A, Aminorraayaee yamini A. Nurses' Awareness of Ethical and Legal Issues in the Care of Elderly Patients. Medical Ethics Quarterly. 2015; 9 (31):169-186 [Persian].

11. Yarian S, Rahian H, Asgharnejadfarid A, Vahedi H, Ameri N F, Dehghan Najmabadi M. Effectiveness of ontological security training on psychological safety and existential anxiety of elder people. joge. 2019; 3 (4) :1-10 [Persian].

12. Khan ahmadi M, Farhood D, Malmir M. Ethical Consideration of Aging: Especially Patients with Alzheimer Disease. Ethics in science and Technology. 2015; 10 (1):1-7. [Persian].

13. Weld, KK. Garmon Bibb, SC. Concept analysis: malpractice and modern-day nursing practice. Nursing Forum. 2009: 44 (1); 2-10.

14. Rangraz Jedi F,Rabiy R. [mizane reayate manshore hoghooghe bimar dar bimarestanhay dolati Kashan]. Behbood. 2005; 1 (9): 62-71.[Persian].

15. Jouzi orkovazi H, Ashktorab T, Abasi M, Delpishe A, Menati R, Shahmir L. Investigating the Organizational Factors Affecting Patients 'Rights from Nurses \& Patients' Views in Hospital Affiliated to Ilam University of Medical Sciences. Medical Ethics. 2013; 7 (23): 142-160. [Persian].

16. Nasiriani Kh, Farnia F, Nasiriani F. Study of respecting patients rights from nurses point of view employed in Yazd hospitals.Journal of Legal Medicine of Islamic Republic of Iran. 2007; 13 
(45)37-33. [Persian].

17. Amini A, Tabrizi J S, Shaghaghi A, Narimani M

R. The Status of Observing Patient Rights Charter in Outpatient Clinics of Tabriz University of Medical Sciences: Perspectives of Health Service Clients. Iranian Journal of Medical Education. 2013; 13 (7) :611-622. [Persian].

18. Ghaljeh M, Khanjani N, sajadi M, Latifi M, Dastoorpoor M. Awareness from patient right patent and its observance from patients' viewpoint. JNKUMS. 2016; 7 (3) :657 - 668. [Persian].

19. Rahmani A, Gahramanian A, Mohajjel-Agdam AR, Allah-Bakhshian A. [Perception of patients regarding respecting to their autonomy during nursing care in hospitals affiliated to Tabriz University of Medical Sciences]. Iranian Journal of Nursing Research. 2008; 3 (9): 7-14.[Persian].

20. Merakou K, Dalla-Vorgia P, Garanis-PapadatosT, Kourea-Kremastinou J. Satisfying patients'rights: a hospital patient survey. Nurse Ethics.2001; 8 (6): 499 - 509.

21. Ghazikhanlo Sani K, Farzanegan Z. Evaluation of patient's right charter observance in view point of personnel and patients in Radiology Wards of Hamadan's educational hospitals in 2015. psj. 2016; 14 (4) :70 - 78. [Persian].

22. Babamahmoodi, F. Meftahi, M. Khademloo, M. Hesamzadeh, A. Observation of patient's right charter in Mazandaran teaching hospitals: patients view. Iranian Journal of Medical Ethics and History of Medicine. 2011.4 (4): 37 - 47.

23. Lin YP, Tsai YF. Maintaining patients' dignity during clinical care: a qualitative interview study. J Adv Nurs 2011; 67 (2): 340-8

24. Dadkhah B, Mohammadi MA, Mozafari N. [Mizane ehteram be mahdudeye ghalamroe va hoghughe bimaran dar bimarestanhaye shahre ardabil]. Journal of Nursing \& Midwifery Research. 2005; 23: 37 - 44. [Persian].

25. Basiri Moghadam K, Basiri Moghadam M, Moslem AR, Ajam Zibad H,Jamal F. Health providers and patients awareness on patient bill of rights and its observing rate in an

26. educational hospital in Gonabad. Ofogh-eDanesh.GMUHS Journal. 2011; 17 (2): 45 - 54. [Persian]. 